https://helda.helsinki.fi

\title{
The Naked, Vulnerable, Crazy Girl
}

\section{Oinas, Outi Elina}

\section{5}

Oinas , O E 2015 , ' The Naked, Vulnerable, Crazy Girl ', Girlhood Studies , vol. 8 , no. 3 , pp. 119-134 . https://doi.org/10.3167/ghs.2015.080310

http://hdl.handle.net/10138/306538

https://doi.org/10.3167/ghs.2015.080310

Downloaded from Helda, University of Helsinki institutional repository.

This is an electronic reprint of the original article.

This reprint may differ from the original in pagination and typographic detail.

Please cite the original version. 


\title{
The Naked, Vulnerable, Crazy Girl
}

\author{
Elina Oinas
}

$\cos$

\begin{abstract}
In this article I explore the concept of the rebellious girl by examining the cases of three different girls: an HIV activist in South Africa; a young feminist in Finland; and a topless on-line protester in post-revolution Tunisia. Although their contexts and messages vary greatly, there are marked similarities between and amongst them. I suggest that, in general, the media, political movements, and research agendas often appear to have difficulty taking girls' protests seriously. The rebellious girl is ridiculed, shunned, shamed, and disciplined. The protests explored here can, however, be read as important visual interruptions that attempt to invoke an epistemic mutiny that does not beg for inclusion on preexisting terms but, rather, challenges the boundaries of acceptable bodily integrity. They also gesture towards the social in a way that demands recognition, acceptance, and support, not a simplified acceptance based on the notion of neoliberal individual freedom.
\end{abstract}

\section{KEYWORDS}

body, feminist politics, girls, protest, rebellion, sociology

\section{Introduction}

The rebellious girl is one of the key icons in the scholarly field of Girlhood Studies, as well as in feminist and mainstream popular culture. Popular culture is inhabited by many girl characters who are constrained by the sexualizing male gaze, patriarchal limitations, or normative expectations, but these stories often underline the agency of the girl who resists (Berlant 2008). The dichotomous oppositionality typical of everyday thinking about the girl who is constrained but who seeks freedom is one of the key issues that feminism and Girlhood Studies attempts to both understand and counter.

The rebellious girl resists a scholarly agenda that solely seeks freedom because a child, by definition, is needy. Support, care, and physical intimacy are essential in childhood, and, some scholars argue, viewing the subject as needy, incomplete and relational could be seen as essential for any age, and adulthood, too (see Lee 2001; Häkli and Kallio 2014). Feminist 
social science on girls balances on the very paradox with which, at heart, all social science research grapples-the limits of a good, protecting yet free society. We cannot settle for models of protection and support that, without resistance, end up being totalizing systems of control, however well-meaning these may be. Working in the field of Girlhood Studies, one quickly notices that the key questions of social theory emerge in even the easiest of small case studies. The rebellious girl actualizes the classic, core questions already there, but she does not settle for the traditional ways of answering them. The girl embodies both relationality and autonomy; freedom and solitude as well as recognition and embeddedness; demand of visibility and voice but also, often, the teenage mumble to just be left alone (Oinas 2001). The explicit and unapologetic disciplining of the girl by conservative voices is argued to be of key importance for societal coherence. Consider, for example, the public interest in abortion rights or veiling across the globe. In order to maintain the disciplined girl as a key symbol of social order, the most effective organizing principle that will keep her on a tight rein is the shame and ridicule attached to unruly girls (Gunkel 2010; Ekine and Abbas 2013).

I will discuss three cases in which such a ridiculing or silencing took place, and will argue that the girl protest is, despite all the difficulties attached to it, actually a social one, embedded in socially intelligible meaning-making. Through a discussion of the protests of Aviwe, Amina, and Annika, I will consider the difficulty with which girls can intervene, claim multiplicity, and escape from the rigid grid that makes a girl intelligible or ridiculous. Connecting their very different protests, in Cape 'Town, Tunis, and Helsinki, may seem, at first, farfetched but I argue that they can and should be discussed parallel to one another since they all deal with the body and shame in similar registers that can be understood through the concept of visual or sensual interruptions.

Unlike the claims made in most fields of social science, in Girlhood Studies there is no ready assumption of progress, especially regarding gender equality in the North. Rather, we witness a continuing, even strengthening, disciplining of girls' embodiment and sexuality in globalizing neo-liberal consumerist esthetics. While there is ample research on restrictions on how girls across the globe are ushered into respectability, Girlhood Studies challenges us to read girls' resistance and submission in new and innovative ways, while acknowledging the importance of remaining context sensitive yet still preventing stereotypical notions of context to hamper our analysis. 


\section{The Material, Desiring Body: Aviwe, Annika, and Amina}

The three cases that I use for my argument here are based on visual images of girls whose presence I have encountered during my research, yet have never met except, in the case of Aviwe, in passing. Here, the lack of personal encounter underlines the way in which girls' stories and bodies are utilized, even appropriated and exploited, in both media and research. Yet, rather than agonizing about the awkward intimacy in a non-encounter I follow Ahmed's (2000) thinking on the inevitability of strange encounters. For me, the truthful encounter with research informants is neither possible nor desirable (Jungar and Oinas 2011). Rather, I see the scholarly analysis as being a discussion with data that, I hope, does something useful in giving us something to think about in the liminal area, constructed by me as the researcher, in between an actual life and the imagined imprint that these girls make in the social world.

Aviwe is a pseudonym for a 14-year-old HIV activist who was interviewed by my research partner in Cape Town in 2003 where we were conducting research on grassroots and global activism on HIV (Jungar and Oinas 2010 , 2011). I met her briefly at rallies and heard her speak in front of 10,000 protesters during one of the larger events. Amina Sboui (she is also known as Amina Tylor) created an upheaval in post-revolution Tunisia with her topless FEMEN protest in March 2013, at a time when our research group Youth and Political Engagements in Contemporary Africa (YOPO), was conducting interviews at the World Social Forum (WSF) in Tunisia. We started asking questions about her protest in the interviews we were conducting about youth and political engagements in contemporary Africa and especially with the young Tunisian WSF volunteers (see Laine et al. 2015; Jabberi and Laine 2014). ${ }^{1}$ Annika is a 14-year-old Finnish girl interviewed for our study on Nordic feminisms (Oinas, Colliander and Rantanen 2005).

\section{The Discursive Materiality of Embodiment: Aviwe}

Aviwe's protest is the most optimistic of the three since she was, temporarily at least, taken seriously. In 2003 the Treatment Action Campaign (TAC) a civic organization that played a prominent role in South Africa in the 2000s (Robins 2004; Nattrass 2007; Oinas and Jungar 2008; Jungar 2011) succeeded in their demand for life-saving medication to be made available to people living with HIV. The campaign worked through a careful contesta- 
tion of the image of the suffering, passive HIV+ victim. Girls like Aviwe marched to make clear the profound injustice at work in a situation in which some global citizens can access medicine while others are left to die. This was evident in the vocabulary of the movement, in her interview account, and also in her simple presence-her visual interruption of who is usually allowed to address parliament — when she was standing on the podium and giving a speech as a self-evident citizen.

Staging herself as a girl child and courageously outing herself both as a victim of sexual assault and a woman living with HIV as a rape survivor whose experience should matter to the state and to the global community, Aviwe expanded the definition of the political agent, blurring the line between public and private, and that between shame and bravery. Given that she was seemingly too small and fragile for the podium her appearance was at odds with the cheering and energetic vibe of the event. She was not a radiant speaker yet she spoke with urgency and in a highly personal tone. As a scholar who has suspiciously examined messages that often operated by fetishizing and sentimentalizing the HIV victim (Jungar and Oinas 2011) I was amazed by the way in which Aviwe spoke against any such reading; while her message was affective her presence did not stress primarily the tragedy of her personal story but the politics of the structural injustices that demand urgent attention.

While Aviwe could explain with ease and elegance in her speech how discourse has socio-economic effects the social science literature then2003 - grappled with the juxtaposition of discourse and political economy (Jungar and Oinas 2010). Further, in South Africa the authenticity of the black women's voices in the movement was being questioned. The TAC was accused of being a façade for a handful of elitist male intellectuals who appropriated the faces of black women for their own politics. Girls like Aviwe were accredited with a token presence and little agency of their own.

Aviwe underlined the importance of material elements, for example public services, for girls like her, but her message also dealt with discursive assumptions of dignity and worth: the lack of medication for some global citizens derives from assumptions about modernity and its myths, and the multiple ways in which some are signified as being less human than others, with some subject positions never fully qualifying for citizenship. She was not recognized as having a life worthy of being saved by her government or by international agents in the early 2000s but her movement eventually won. Her own voice was deemed to be hypervisible for others' political gain, when she, ostensibly duped and manipulated, marched for her rights. 
Some activists are recognized by the media, general public, and researchers, while the politics of others remain suspect. "Academic progressives tend to respect and take seriously only what is convertible to their vision of politics," claims Berlant (2008: 26). In his recent book Julian Brown (2015) emphasizes the need to include in the realm of the political those who had no access earlier or who were not seen. As a feminist I ask why Brown's suggestion is presented as novel even if I agree with him that the need to focus on the unexpected politics of insurgent citizens is still, or perhaps even increasingly, important. Even more disappointing is the fact that the book includes no mention of girls like Aviwe, or of feminism. Despite his thorough work on South Africa's landscape of activism, girls as individuals, groups or even as a category, are nowhere to be seen. Pointing at Brown would be unfair were it not for his explicit emphasis on valorizing those previously not recognized as political actors. Overall, failing to notice girls' protest is more rule than exception. Aviwe's presence on the podium, and the public failure to recognize her girlness as significant along with her specific vulnerability, calls for questions about subversion and resistance: how can hypervisibility, racialization, and denied subjectification be profoundly challenged by, for example, racialized and hypersexualized black girls seeking affirmation, without being read through the very categories they wish to resist?

\section{The Rejection of a Silent Subjectification to a Melancholic Heroine: Annika}

The image of Annika, a privileged girl from one of the richer suburbs of Helsinki, Finland, could epitomize the ultimate counterpart of Aviwe. She was part of a middle-class girls' soft-feminist after-school activity group that was founded by an NGO for health promotion to support healthy selfesteem among girls who were seen to be prone to, for example, anorexia.

The connections between the two 14-year-olds are striking, despite the differences in context. In Annika's case I am intrigued by the visual images she brought up in the interview, most of which dealt with her anxiety about her body. She describes, however, one image that interrupts the narration: she enters the girls' group room, a space where she feels safe, and she relaxes. It is a space where they talk about the visual appearance and a performative of the self in a critical, and according to Annika, empowering way: "There you know that everyone, or quite many, feel, somehow, quite uncertain; that 
it is not so that everyone else goes around and seems like the most beautiful in the world, as you might sometimes think" (quoted in Oinas, Colliander and Rantanen 2005: 219).

Aviwe and Annika both pointed to activism as a way of becoming aware of the structural circumstances that shape and limit, and enable their lives. This politicized awareness was a way of overcoming the stigma and shame associated with being a teenage girl. While the injustice of poverty and violence was the context of Aviwe's story, Annika points to the neo-liberal ethos of being the slim, popular, cool, and smart girl, an ideal of a global heroine she finds crushingly hard to live up to. The groups, the TAC and the NGO's self-esteem one, were a breathing space for both girls since in these they developed a political thinking that enabled resistance, and, importantly, embeddedness in a movement for collective resistance and transformation.

For Annika the fear of possible failure to be the embodiment of the liberated modern girl was culturally silenced, with the exception of her group that actively attempted to counter the culture of silenced melancholia. The figure I have referred to elsewhere (Oinas 1998) as the empowered smart girl was a strikingly lonely character in Annika's account. Annika felt unable to voice her conflicting desires because of the strong middle-class feminist agenda of her social surroundings.

People can say, like, 'well girls, be feminist, and strong, and you don't need a boyfriend,' and like that, and then you think that, 'yes, but I want a boyfriend' and 'no, no, they say.' There are huge differences in what you should be and what you are .... But it is so difficult to hold on to those ideals, like afterwards, when you have left the Girls' Group and sit there in the class room, and you look at the good looking guy. He is dating the one with the right clothes and you are there in the ugly jeans. But really, you should never mind (quoted in Oinas, Colliander and Rantanen 2005: 230).

Young women's interest in their looks and sexuality is criticized constantly as being vain and self-absorbed, and as lacking a politically bigger picture along with concern for wider issues. In the interview Annika identified this criticism, found also within some feminisms, and it seems that her group had helped her work on these contradictions. The accusation of vanity may miss the ways in which girls' activism in relation to embodiment and appearance translate to wider issues of individuality, neo-liberal ideals, and consumer capitalism, and, further, to global inequalities through, for example, a critique of consumption, production, and value chains. The classic divide between the private and the public renders Annika's body politics-significantly life-changing and horizon-expanding for her-to a petty 
preoccupation with her own appearance and attractiveness. Girls' concerns are often not seen as political enough; after all, they are about girls who do not really matter.

\section{Epistemic Interruption at the Margins of the Intelligible: Amina}

The 19-year-old Tunisian, Amina, posted a photo of herself, topless and bearing in Arabic on her chest the text, "my body belongs to me, and is not the source of anyone's honor" on the FEMEN Tunisia website she established in March 2013. This turned her immediately into a global celebrity. The events that followed included calls by a Tunisian religious leader for Amina to be stoned to death for possibly inciting an "epidemic" that gives "ideas to other women" (Namazie 2013: n.p.); a brief episode in a mental institution; FEMEN's support and an international campaign; detention (also of her supporters); her withdrawal from FEMEN; and during all this, the posting of hundreds of internet comments on the relevance of the photograph. She published a book in French (2014) that has already been translated into Italian and Turkish, in which she documents her own account of this protest, so my interest here is not to document the factual unfolding of events, nor Amina's own intentions, but the ways in which her protest was received and made intelligible, or not.

The reactions to Amina touch upon a variety of issues: contemporary tensions regarding transnational feminisms; cultural conservatism; generational clashes; politicized embodiment and shame; public sexualization; and changing fundamentalisms, especially Islamophobia and Western imperialism. While FEMEN has challenged global feminist movements and provoked unusually explicit anger, ridicule, and dismissal among women's movements and conservative religious authorities alike, one could assume that it could evoke, potentially, other types of responses from activist youth, especially in the aftermath of the initial revolution and later frustration in Tunisia. A generational conflict on issues of rights and freedoms and bodily integrity has been of crucial importance to young women in the North African revolutions (Honwana 2013; Jabberi and Laine 2015; Onodera 2015).

Since my research group happened to be in Tunis the week after the picture was posted, we asked young university and high school students we interviewed $^{2}$ to say what they felt about the meaning, or meaninglessness, of Amina's action and the resultant media turmoil. The interviews confirmed 
that she had quickly become a celebrity; everybody knew about her. But, she made people uncomfortable. "Amina goes too far; she may make change more difficult," was a common answer. Only one person, a 19-year-old man, said Amina's protest was exciting. For him she placed the problem of gerontocracy and the right to define young people's struggles in the center.

The way the protest was discussed in the media and on internet blogs replicated the sense of discomfort. There was a strong tendency to evoke stereotypical dualisms about the Muslim world and the West. Many commentators from a self-identified Muslim point of view expressed the worry that the photo and the FEMEN context would fuel the anti-Islam sentiment that already exists. The comments presupposed that there is no space for a nuanced feminist discussion but we have to remember that any depiction of women's issues in the Middle East reproduces the same sensationalist images that lack background context and detail. FEMEN itself instigated this debate since it had at the time an explicitly Euro-centric approach stated clearly on its website. While FEMEN could be read as a specific feminist protest in post-socialist neo-capitalist patriarchy, the discussions about Amina remained stuck along the West-Islam axis.

An important framework for an analysis of the internet comments is, of course, the actual gender politics in Tunisia that become largely simplified and inevitably distorted in cyberspace. There are strong women's movements in Tunisia, and a widely accepted belief that Tunisia has a unique history of achievements in the societal positions of women. Many different groups share a concern that the aftermath of revolution may also bring about forces that threaten the existing freedoms of women. Feminist debate in Tunisia has space in the public realm, and it has energy, diversity, and voice. The assumption that there is a silence that FEMEN needs to break is insulting to the long history of women's agency in Tunisia. The juxtaposition of Islam and the West and the lack of contextual awareness thus overshadowed the discussion of what Amina's protest could mean; any other interruption that Amina might have wanted to provoke was foreclosed. In light of her later stance and withdrawal from FEMEN, we know that discussing pro- or antiMuslim stances and fueling Islamophobia was not her intention.

In my reading, next to Annika's and Aviwe's protests, Amina's photo links easily to many other protests beyond any religious or geographical juxtaposition. It unsettles an image of decency and vulnerability, and acts as an open provocation about embodiment and honor, and girls' space for pleasurable solitude. This provocation is a shared one across cultural divides, with different expressions depending on context. For example, Annika expressed 
similar longing for embodied integrity, but saw no way of voicing this in public, despite her small feminist group and her experienced emancipation.

Without questioning the importance of context specificity when we are analyzing on-line protests, we can see that many young women around the world share concerns that go beyond place and time. Understanding Amina only through Islam or FEMEN stops us from seeing similarities in girls' protest in contemporary popular culture and virtual spaces. Also, the feminist comments on what Amina did remind us of the difficulty young women experience in having what they do by way of protest being read as serious yet open-ended political rebellion. Amina's action was dismissed as that of a girl who causes harm because she fails to understand the context of Islamophobia.

\section{Uninformed, Silly, Emotional}

The comments on Amina follow the long tradition in which young people's rebellion is disregarded as silly, emotional, or ignorant. She is seen to be unaware of the complexity she is trying to address; her experienced anger is not sufficient. Ridiculing and trivializing girls' attempts to make space for new thinking is a global cultural attack on girls' politics, perhaps because girls' decency matters so much. Amina's case shows how a girl's protest that has to do with embodiment and sexuality-both so carefully policedevokes reactions of pity and protection, both more powerful tools in the silencing of girls than taking them seriously. The fierce reaction by religious leaders granted her more credibility than did the online belittling in portrayals of her as the exploited, naïve puppet girl.

Annika's concerns and their resonance with Aviwe's plea that we are all affected by the structures of power, can be read as a radical critique of neoliberal capitalism that divides subjects into those from the North and those from the South, either privileged or oppressed (as though freedoms can be measured along a single track of development). Seeing beyond such dichotomies, without erasing difference and privilege, is what Girlhood Studies, in my view, should be doing; we need a wider debate on whether the dualisms cover up more than they reveal.

In material terms, the privilege of Annika's comfortable life is undeniable, but, following Spivak, all these girls are offered "abject scripts" (1990: 62) to live by, and, because of their engagement in activism, they are willing to look for new ways to conceptualize meaningful horizons. Annika may, in her body 
pre-existing Western modernity, but a call for a new justice, a thorough reconceptualizing of freedom. Sara Ahmed, in her recent book, examines the difficulty of theorizing the willful girl.

Willfulness too has been understood as an error of will. Let's take a typical definition of willfulness: asserting or disposed to assert one's own will against persuasion, instruction, or command; governed by will without regard to reason; determined to take one's own way; obstinately self-willed or perverse. .... This intimacy of willfulness and unhappiness remains to be thought. And to think that intimacy is to queer the will" (2014: 4).

Inclusion in the epistemic domain, but not on the old terms, is the call made by many young activists, but it requires a queering of the existing tools of political science. The paradigm that has othered and excluded queers, women, girls, and post-colonial communities, the odd subjects-alternative knowledge systems as well as their agents-must not welcome the subalterns but give way to new epistemic openings. Inclusion to the old order is not an alternative (Fanon 1963).

Corporeal and social nakedness, vulnerability and exposed desire establishes the issue of sexuality and pleasure in such a way that a protest becomes a social one, not one for self-determination, freedom, and autonomy only. Sex is often mutual; even if only in fantasy, there is a counterpart, a bond, a touch or a gaze of sorts (Bhana 2013). A positive girly lusty sexuality is a global question mark. Nowhere can girls enjoy their naked bodies without taking a risk; nowhere is a public protest involving a girl's right to her body and sexual pleasure, especially heterosexual pleasure, a space in which girls can count on an environment that supports their pledge within the appropriate regimes of engagement. There seems never to be any appropriateness for girls' protest to widen the scope of regimes of heterosexuality. In Amina's sexual pose and open vulnerability there is a reminder that young women's and girls' sexual desire and desire to be desired exposes them to humiliation, violation, and ridicule.

One blogger who begins with defending an eroticized, naked protest moves to calling it dishonest: "It is entirely understandable that a young modern woman would want to have her beauty admired; to hide this desire behind a claim to fight for freedom of speech and women's lib is a bit dishonest." (Salem 2012: n.p.). Curiously, the writer detaches the longing for erotic admiration from a fight for freedom. The struggle for ownership of an erotic body, and the demand for a right to make this call public and full of social meaning, appear to be difficult to combine with pleasure that remains apolitical.

Without claiming that FEMEN in general is the way to go, I would suggest that we should be paying attention to the ridiculing of girls' protests 
as a legitimate space in which to discuss erotic desire and the desire to be desired in non-humiliating ways. Their protest undermines so much of our epistemic social reality that it steps outside the normative in a dramatically radical way, therefore not really fitting into the negotiation model of political sociology. The (naked) pose of the Other cannot be seen by the lens of sociology when it is too provocative and irrational. Halberstam probably cheers for this, but as a sociologist in Girlhood Studies I believe this state of affairs should challenge us to work with political science rather than letting it be.

\section{Conclusion}

I have used three cases to illustrate how girls' protest is often ridiculed, shunned, or belittled as silly, ignorant, limited, or too self-interested to be really seriously political. At times it is deemed irrational, which leads a Girlhoods Studies scholar to ask, with Halberstam (2012) and Gunkel (2012): So what if it is irrational? Irrationality might be exactly the visual interruption the pose wishes to use to meet such limiting, oppressive rationality.

Even when I am drawing from a register of irrational, insane, apocalyptic protest, as a sociologist, I would still suggest that there is an element of sociality in all the protests I have discussed here. Even when a girl's lonely pose signals a radical shift in her epistemic struggle towards something yet unintelligible, there can be a longing to be taken in, taken seriously. The girls discussed here may long for freedom-individual freedom to self-expression, bodily integrity and sexual desire that should not be read as inherently Western but as universal ideals. Following a long list of feminists theorizing subjectivity, including, of course, Butler (1990) I think that such freedom is by no means in a dichotomous relationship with social recognition and the embeddedness of the self. The girl who desires freedom is not by necessity longing for the neoliberal subject position of a consumerist lonely heroine.

The struggles of girls globally for freedom often have to do with symbolic, discursive ideals regarding, for example, bodily decency and sexuality, but as Amina, the HIV+ activist girl reminds us, there is no distinction between the ideal and the material body. The materiality of lives is not a separate theme that more culturally oriented scholarship can forget about. Access to life-saving medication, for example, is a matter that requires both a socio-economic and epistemic change in thinking, as well the inclusion of political acts to ensure the delivery of medical services along with re-thinking the definition of which bodies are worthy of saving. 
Research on girls, alongside the sociology of childhood, has been compelled to take the intertwinement of the material, the social, and the cultural seriously since there is a clear link between freedom and care. A child cannot be set free unless she or he is cared for. The figure of the rebellious girl demands that we, as scholars, sharpen our analytical tools to the extent that we are able to deal with the challenge of relationality and autonomy, embeddedness, recognition, individuality, and freedom as simultaneous processes. Girlhood Studies suggests that we owe her at least an attempt to do this. Her visibility, her voice, or her hope of just being left alone, more often than not has a radically political message that should not be met by silencing, ridiculing, or belittling her.

It is not that Girlhood Studies looks for anything yet unexplored. In queer theory there is a tradition of socially embedded, embodied interdependency in, for example, Judith Butler's writings on precarity (Butler 2012). For Butler, the embodiedness of life exposes our sociality and requires that social trust, vulnerability, and desires are acknowledged. Girlhood Studies, however, expands the research agenda by working with empirical data, engaging with the contemporary struggles of girls worldwide.

$\cos$

Elina OINAS is a professor of Sociology at the University of Helsinki, Finland. Currently she leads a research consortium on Youth and Political Engagements in Contemporary Africa, funded by the Academy of Finland (258235) with Leena Suurpää. She is interested in feminisms, girls, health, and the body in different locations and transnationally. She has worked in different universities in Finland in Sociology, Gender Studies, and Development Studies, as well as in Uppsala, Berkeley, and Cape Town. She was the editor of NORA-Nordic Journal of Feminist and Gender Research with Tutta Palin from 2007 to 2009.

\section{Notes}

1. Amina is the only one who was not personally encountered by anyone in my research team, and is, thus, in a sense, even more of a fictional character here. Her own account of the events has, however, been published (Sboui 2014). While I have published other texts on data of the two other girls, Amina's case is new to me. Here I find her presence alongside the other two intriguing but I acknowledge that the case deserves a more thorough analysis. In this article the thoughts inspired by Amina nevertheless ended up taking most space, perhaps overshadowing the two girls more familiar to me, even if they were, in the analysis, constantly in an imagined conversation with each other. 
2. Roughly 50 interviews, of which 10 commented on Amina, were conducted in March 2013. The search for on-line material was conducted between 2013 and 2015 and the results are comprised of about 100 entries.

\section{References}

Ahmed, Sara. 2000. Strange Encounters: Embodied Others in Post-Coloniality. London: Routledge.

Ahmed, Sara. 2014. Willful Subjects. Durham: Duke University Press.

Alasuutari, Pertti, and Ali Qadir. 2014. "Epistemic Governance: An Approach to the Politics of Policy-making." European Journal of Cultural and Political Sociology 1, no. 1: 67-84.

Berlant, Lauren. 2008. Female Complaint. Durham: Duke University Press.

Bhana, Deevia. 2013. "Introducing Love: Gender, Sexuality and Power." Agenda 27, no. 2: 3-11.

Brown, Julian. 2015. South Africa's Insurgent Citizens. On Dissent and the Possibility of Politics. London: Zed Books.

Butler, Judith. 1990. Gender Trouble. New York: Routledge.

Butler, Judith. 2012. Precarious Life. London: Verso.

Ekine, Sokari, and Hakima Abbas. 2013. Queer African Reader. Oxford: Fahamu Books/Pambazuka Press.

Fanon, Frantz. 1963. The Wretched of the Earth. New York: Grove Press.

Gunkel, Henriette. 2010. The Cultural Politics of Female Sexuality in South Africa. London: Routledge.

Gunkel, Henriette. 2012. "Introduction: Politics of Visibility." Pp. 130-140 in Undutiful Daughters, ed. Henriette Gunkel, Chrysanthi Nigianni and Fanny Söderbäck. New York: Palgrave Macmillan.

Halberstam, Jack. 2012. "Going Gaga: Dissent, Refusal and Feminism.” Pp. 184-194 in Undutiful Daughters, ed. Henriette Gunkel, Chrysanthi Nigianni and Fanny Söderbäck. New York: Palgrave Macmillan.

Honwana, Alcinda. 2013. Youth and Revolution in Tunisia. London: Zed Books.

Häkli, Jyrki, and Kirsi P. Kallio. 2014. "Subject, Action and Polis: Theorizing Political Agency." Progress in Human Geography 38, no. 2: 181-200.

Jabberi, Fatma, and Sofia Laine. 2015. "Spaces of Dialogue? The Case of the World Social Forum Tunis 2013 from the Perspective of Young, Local Volunteers." Global Studies of Childhood 5, no. 2: 178-190.

Jungar, Katarina, and Elina Oinas. 2010. "A Feminist Struggle? South African HIV Activism as Feminist Politics." Journal of International Women's Studies 11, no. 4:177-191. http://www.bridgew.edu/soas/jiws/May10/JIWS_Vol_11_ no._1_Feminist_activism_HIV_S._Africa_FINAL_Formatted.pdf (accessed 4 May 2012). 
Jungar, Katarina. 2011. Long Live! South African HIV Activism, Knowledge and Power. Turku: Åbo Akademi University Press.

Jungar, Katarina, and Elina Oinas. 2011. "Beyond Agency and Victimization: Re-reading HIV and AIDS in African Contexts." Social Dynamics 16, no. 3: 248-262.

Laine, Sofia, Elina Oinas, Leena Suurpää, Tiina-Maria Levamo, Henri Onodera, Piia Lavila, and Rantama Minna. 2015. "Polyphonic Ethos in Team Research: Lessons from the World Social Forum, Tunis 2013." Pp. 116-135 in "In Search of" New Methodological Approaches to Youth Research, ed. Airi-Alina Allaste and Katrin Tiidenberg. Cambridge: Cambridge Scholars.

Lee, Nick. 2001. Childhood and Society. Cambridge: Open University Press. Namazie, Maryam. 2013. "Nothing is Sacred."http://freethoughtblogs.com/ maryamnamazie/2013/03/21/4-april-2013-international-day-to-defendamina-she-represents-us/ (accessed 04 September 2015)

Nattrass, Nicoli. 2007. Mortal Combat: AIDS Denialism and the Struggle for Antiretrovirals in South Africa. University of KwaZulu-Natal Press.

Oinas, Elina. 2001. Making Sense of the Teenage Body. Turku: Åbo Akademi University Press.

Oinas, Elina, Anna Colliander, and Eveliina Rantanen. 2005. “'Girl group' Activities: Empowerment, Discipline, Health Literacy?”. Pp. 219-238 in Beyond Health Literacy, eds. Tommi Hoikkala, Pekka Hakkarainen and Sofia Laine. Helsinki: Finnish Youth Research Network.

Oinas, Elina, and Katarina Jungar. 2008. "A Luta Continua! South African HIV Activism, Embodiment and State Politics." Development Dialogue, no. 50: 239-258.

Onodera, Henri. 2015. Being a Young Activist in the Late Mubarak Era: An Ethnography of Political Engagement in Egypt. Helsinki: University of Helsinki, Department of Political and Economic Studies.

Robins, Stephen. 2004. “Long Live Zackie, Long Live': AIDS Activism, Science and Citizenship after Apartheid." Journal of Southern African Studies 30, no. 3: 651-672.

Salem, Sara M. 2012. “Femen's Neocolonial Feminism: When Nudity Becomes a Uniform" http://english.al-akhbar.com/content/femens-neocolonialfeminism-when-nudity-becomes-uniform (accessed 24 July 2015).

Sboui, Amina. 2014. Mon corps m'appartient. Paris: Plon.

Spivak, Gayatri Chakravorty. 1990. "Questions of Multiculturalism.” Pp. 9-68 in The Postcolonial Critic: Interviews, Strategies, Dialogues, ed. Sarah Harasym. London: Routledge.

Thévenot, Laurent. 2014. "Voicing Concern and Difference: From Public Spaces to Common-places." European Journal of Cultural and Political Sociology 1, no. 1: 7-34. 